\title{
Investigating the Potentials of Sluice Box Angle of Tilt on the Beneficiation of Birnin-Gwari Gold Deposit
}

\author{
Oladunni O. Alabi and Yemisi E. Gbadamosi \\ Department of Metallurgical and Materials Engineering, Federal University of Technology, Akure, Nigeria \\ aoalabi@futa.edu.ng | gbadamosiyemisi.e@gmail.com
}

Received: 22-FEB-2021; Reviewed: 18-APR-2021; Accepted: 07-MAY-2021

http://dx.doi.org/10.46792/fuoyejet.v6i2.620

\begin{abstract}
The potentials of sluice box angle of tilt on the beneficiation of Birin-Gwari gold deposit was investigated. The sample was sourced from twenty (20) pits on the mine site and homogenized towards chemical characterization. Particle size analysis using $100 \mathrm{~g}$ head sample over the sieve range of $500 \mu \mathrm{m}$ and $45 \mu \mathrm{m}$. $100 \mathrm{~g}$ each of the homogenized samples was charged into the sluice box at varied tilt angles ranging from $10^{\circ}$ to $60^{\circ}$ and also at a varying feed rate of $50 \mathrm{~kg} / \mathrm{hr}$ to $100 \mathrm{~kg} / \mathrm{hr}$ at $1000 \mathrm{~m} / \mathrm{s}$ flow rate. The Energy Dispersive X-ray Fluorescence Spectrometry (ED-XRFS) revealed $10.15 \mathrm{ppm} \mathrm{Au}, 0.43 \% \mathrm{Fe}, 0.05 \% \mathrm{~Pb}$, and other constituent elements in trace form. Particle size analysis showed the liberation size to be $-125+90 \mu \mathrm{m}$. The highest yield in mass was given as $32.70 \mathrm{~g}$ assaying $43.20 \mathrm{ppm}$ at an angle of $10^{\circ}$ and varied feed rate while keeping other parameters/constituent constant and also, $56.32 \mathrm{~g}$ was the highest yield in mass assaying $12.83 \mathrm{ppm}$ at $50 \mathrm{~kg} / \mathrm{hr}$ feed rate.
\end{abstract}

Keywords- Birnin-Gwari gold, Beneficiation, Characterization, Sluice box

\section{INTRODUCTION}

The developing state of the Nigerian mining industry has led to the importation of materials that can be domestically produced, despite being endowed with varieties of solid minerals. As an avenue for facilitating the growth and sustainability of the economy, the development of these said minerals must be critically addressed. Consequently, gold ore, one of the prominent mineral endowments in Nigeria, has been undergoing a significant exploratory phase as a part of the 2021 agenda of the Nigerian government to re-commence gold exploitation (Okwumbu, 2020). This initiative is hoped to encourage potential investors to take advantage of the opportunities offered by exploring these minerals.

Gold mineralization in Nigeria occurs across the northern belts down to parts of the southern belts. Prominent deposits are Iperindo Osun state, Maru, TsohonBirninGwari, Kwaga, Melele, Anka, Gurmana, Bin-yauri, and Okolom-Dogondaji. Other states with a trace of gold are Abia, Abuja, Bauchi, Edo, Cross-River, Niger, Sokoto, Oyo, Kebbi, Kaduna, Kogi, and Zamfara State (MMSD 2010; Kankara and Darma, 2016). The evidence of massive gold mineralization in Nigeria and continuous appreciation in the global gold demand depict immense leverage it has on a country's gross domestic product (GDP); should these deposits be optimally exploited. Gold, a rare and precious metal, is not only utilized as electrical connectors in all types of computerized devices (its chief industrial use), but also as a neutron reflector in nuclear weapons, and for coinage, jewellery, and other arts throughout recorded history. Gold is also used in infrared shielding, coloured-glass production, gold leafing, and tooth restoration. Certain gold salts are used as an anti-inflammatory in medicine (Duckenfield, 2016).

\footnotetext{
*Corresponding Author

Section D- MATERIALS ENGINEERING \& RELATED CHEMICAL SCIENCES Can be cited as:

Alabi O.O. and Gbadamosi Y.E. (2021): Investigating the Potentials of Sluice Box Angle of Tilt on the Beneficiation of Birnin-Gwari Gold Deposit, FUOYE Journal of Engineering and Technology (FUOYEJET), 6(2), 88-91. http://dx.doi.org/10.46792/fuoyejet.v6i2.620
}

\subsection{Geological Setting and Gold Mineralization OF THE STUDY AREA}

The TsohonBirnin-Gwari gold (Figure 1) deposit is located in the north-western axis of Kaduna state bounded by the geological coordinates, latitude $10^{\circ} 40^{\prime} 0^{\prime \prime} \mathrm{N}$ and longitude $6^{\circ} 32^{\prime} 0^{\prime \prime} \mathrm{E}$. The geological setting of BirninGwari is characterized by two geological terrains, the basement complex, and the schist belts. The Basement complex is overburdened by gently immersed Cretaceous sediments of the lullemmeden basin in the North West and the Bida basin in the South West. While the schist belts are sectioned into two main categories. The BirninGwari deposit belongs to the Kusshaka schist belt characterized by coarse to a fine-grained trivial mafic igneous rock composed mainly of phyllites and iron formations (Garba, 2002). The TsohonBirnin-Gwari goldreef system is about $7 \mathrm{~km}$, mainly associated with pyrite and minor sphalerite, chalcopyrite, pyrrhotite, galena, and magnetite. The gangue is predominantly quartz, but K-feldspar and graphitic matter (from wall rocks) are also constituents. Grades are very variable within the reef system and between oxide and sulphide ore zones, but generally, 5-100 g/t Au are found (MMSD 2010; Garba, 2002).

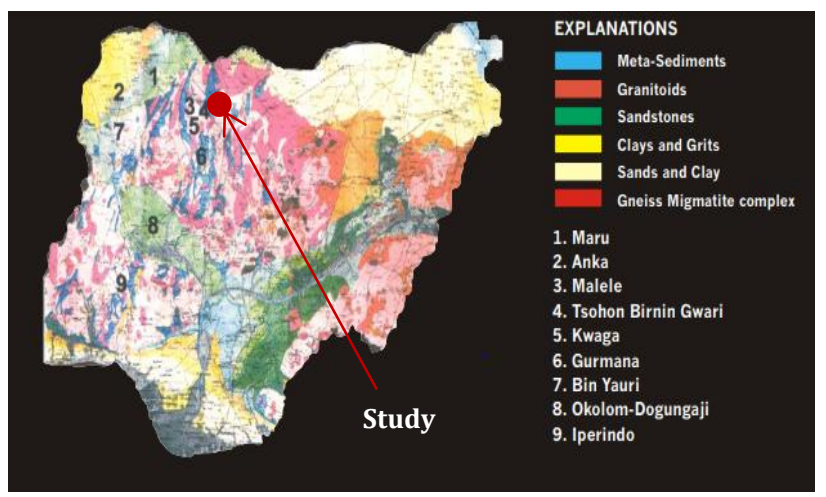

Fig. 1: Geological map show gold mineralization in Nigeria and the study area (Kankara and Darma, 2016) 


\subsection{Gold ORE BenEFICIATION}

Only a few mined ores contain sufficient metal concentrations that require no beneficiation processes. Most gold ores contain a relatively small amount of valuable metal, from perhaps a few percent in the case of base metals which are commonly intergrown with economically important and unimportant (gangue) minerals on a microscopic scale in the iron ore gangue (Metso Mining and Construction, 2015). The separation of these economically valuable minerals from associative gangue can be achieved via processes such as gravity, magnetic, and floatation concentration processes. Gravity techniques continue to play a significant role in the beneficiation of precious and alluvial minerals, such as gold ores. The fundamental principle of settling materials in any medium under the influence of gravity is exploited to separate the gold nuggets (Agyei and Gordon, 2017). One of the prominent gravity separators utilized is the sluice (Figure 2) which is inclined, having flat-bottomed troughs that are lined on the bottom with a trapping mechanism, like carpets or riffles, that captures gold particles and other heavy minerals.

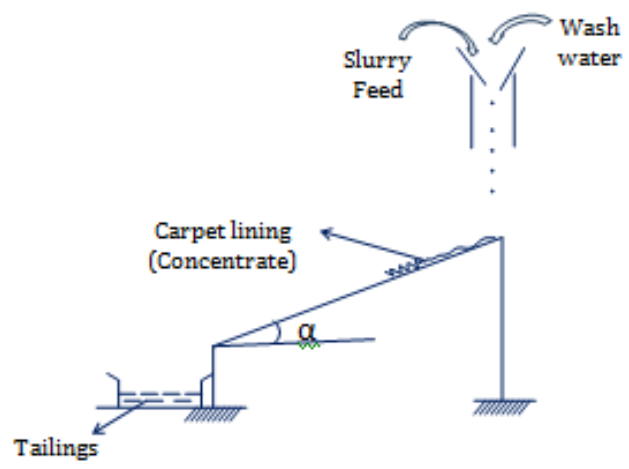

Fig. 2: 2D Schematic diagram of a Sluice Concentrator (Selfcreated)

Sluice operation is premised on the tendency of heavy particles to sink to the bottom of a flowing stream of the slurry while the lighter particles are conveyed downstream and discharged off at the end of the sluice. The trapping mechanism retrains the gold nuggets settled at the bottom of the slurry stream from being lifted off by turbulent forces. Several parameters have been observed to affect the separation efficiency of sluices, among which are the slurry flow rate, inclination angle, and pulp density. Therefore, this research seeks to appraise the effect of the variation of flow rate and inclination angle on the separation effectiveness of sluices for the beneficiation of the Birnin-Gwari gold deposit.

\section{Materials AND Method \\ 2.1 MATERIAL SOURCING AND PREPARATION}

Samples of the gold sand were sourced from twenty (20) pits across the Birnin-Gwari gold mine site, Kaduna State, Nigeria. The collected samples were homogenized into a uniform mix, out of which $100 \mathrm{~kg}$ sample was weighed out for the research.

\subsection{Chemical Characterization of Crude Sample}

Chemical characterization of the crude sample was carried out using an Energy Dispersive X-ray Fluorescence Spectrometer in which $100 \mathrm{~g}$ of the sample was finely ground and $20 \mathrm{~g}$ was sampled out to pass through a 250-mesh sieve. Then, the sample was intimately mixed with a binder in the ratio of $5.0 \mathrm{~g}$ sample to $1.0 \mathrm{~g}$ cellulose flakes binder and pelletized at a pressure 5 of 10-15 tons/inch ${ }^{2}$ in a pelletizing machine. At this stage, the pelletized sample(s) was then stored in a desiccator before analysis. The ED-XRF machine was warmed; the sample was then placed in the machine's chamber and thereafter ran using the appropriate program to determine the various elements therein. The result of the analysis was either reported in parts per million (ppm) or percentage (\%) for minor and major concentrations of elements.

\subsection{Particle Size Analysis of Birnin-GwaRi Gold SAND}

Fractional sieve analysis of a $100 \mathrm{~g}$ sample of the gold deposit was carried out using sieves of a size range of 500 $-45 \mu \mathrm{m}$ to determine the liberation size of the valuable mineral (Wills, 2006). The sample was charged into the upper sieve and the sieve sets were agitated for 30 minutes. Consequently, the undersize particles fall through successive sieves until they are retained on a sieve having apertures slightly smaller than the diameter of the particles (Wills, 2006). The set of sieves were separated and the weight retained on each was recorded. Samples were collected from each size fraction for chemical analysis via ED-XRF.

\subsection{Beneficiation of Birnin-Gwari Gold SAND Via SLUICE BOX}

Two (2) kg of the gold sand was crushed and pulverized to $100 \%$ passing $90 \mu \mathrm{m}$ sieve (established liberation size of the gold sand), and thoroughly homogenized. The homogenized sample was pre-treated to remove unwanted materials such as stones and debris. Then, a $100 \mathrm{~g}$ sample was weighed out and mixed with $1000 \mathrm{~cm}^{3}$ of water to form a slurry. The sluice box was set up at an inclination angle of $10^{\circ}$, thereafter the slurry was charged into the hopper of the sluice system at a feed rate of $50 \mathrm{~kg} / \mathrm{hr}$. Then, wash water was introduced successively at a flow rate of $100 \mathrm{~m}^{3} / \mathrm{hr}$. The resulting products (gold concentrate and tailing) were then allowed to settle for 12 hours and thereafter decanted and filtered. The resulting cake of the product was then sun-dried. The above procedure was repeated at feed rates of $60 \mathrm{~kg} / \mathrm{hr}$., 70 kg/hr., 80 kg/hr., 90 kg/hr., and $100 \mathrm{~kg} / \mathrm{hr}$. Subsequently, the inclination angle was also varied as $10^{\circ}, 20^{\circ}, 30^{\circ}, 40^{\circ}$, $50^{\circ}$, and $60^{\circ}$ at a constant feed rate of $50 \mathrm{~kg} / \mathrm{hr}$. Then, samples were collected from each set of conditions for chemical analysis.

\section{RESULTS AND DISCUSSION 3.1 RESULTS}

The results obtained are presented in Tables $1-4$ and Figures $1-2$. 
Table1. Chemical Composition of Crude Birnin-Gwari Gold Sand

\begin{tabular}{ccccccc}
\hline $\begin{array}{c}\text { Chemical } \\
\text { Composition }\end{array}$ & ${ }^{*} \mathrm{Au}$ & $\mathrm{Fe}$ & $\mathrm{Cu}$ & $\mathrm{Zn}$ & $\mathrm{Pb}$ & $\mathrm{Ag}$ \\
\hline $\begin{array}{c}{ }^{*} \mathrm{ppm} / \% \\
\text { Composition }\end{array}$ & 10.15 & 0.43 & $\mathrm{ND}$ & 0.05 & 0.43 & $\mathrm{ND}$ \\
\hline
\end{tabular}

ND-Not Detectable

Table 2. Fractional Sieve Size Analysis of Birnin-Gwari Gold Sand

\begin{tabular}{|c|c|c|c|c|c|c|}
\hline $\begin{array}{c}\text { Particle Size } \\
\text { Range } \\
(\mu \mathrm{m})\end{array}$ & $\begin{array}{c}\text { Nominal } \\
\text { Aperture Size } \\
(\mu \mathrm{m})\end{array}$ & $\begin{array}{c}\text { Weight } \\
\text { Retained } \\
\text { (g) }\end{array}$ & $\begin{array}{c}\% \\
\text { Weight } \\
\text { Retained }\end{array}$ & $\begin{array}{c}\% \text { Cumulative } \\
\text { Weight } \\
\text { Retained }\end{array}$ & $\begin{array}{c}\text { \% Cumulative } \\
\text { Weight } \\
\text { Passing }\end{array}$ & $A u(p p m)$ \\
\hline+500 & 500 & 81.60 & 8.17 & 8.17 & 91.83 & ND \\
\hline$-500+355$ & 355 & 25.00 & 2.50 & 10.67 & 89.33 & 0.36 \\
\hline$-355+250$ & 250 & 78.80 & 7.89 & 18.56 & 81.44 & 0.87 \\
\hline$-250+180$ & 180 & 75.00 & 7.51 & 26.07 & 73.93 & 0.42 \\
\hline$-180+125$ & 125 & 201.20 & 20.15 & 46.22 & 53.78 & 0.38 \\
\hline$-125+90$ & 90 & 96.00 & 9.61 & 55.83 & 44.17 & 4.42 \\
\hline$-90+63$ & 63 & 208.80 & 20.91 & 76.74 & 23.26 & 1.21 \\
\hline$-63+45$ & 45 & 193.54 & 19.38 & 96.12 & 3.88 & 2.52 \\
\hline-45 & - & 38.80 & 3.88 & 100.00 & 0.00 & 0.05 \\
\hline
\end{tabular}

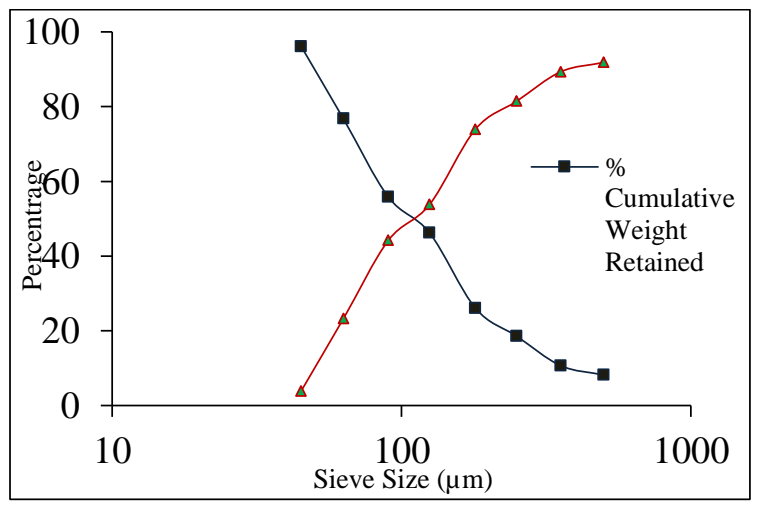

Fig. 1: Plot of log of sieve size $(\mu \mathrm{m})$ against the percentage cumulative retained and pass obtained from the fractional sieve size analysis of Birnin-Gwari gold sand

Table 3. Assay and \% recovery of Birnin-Gwari gold sand obtained at different inclination angles

\begin{tabular}{ccccccc}
\hline $\begin{array}{c}\text { Inclination Angle } \\
\text { (deg.) }\end{array}$ & $\begin{array}{c}\text { Feed } \\
\text { Weight } \\
\text { (g) }\end{array}$ & $\begin{array}{c}\text { Concentrate } \\
\text { weight } \\
\text { (g) }\end{array}$ & $\begin{array}{c}\text { Tailing } \\
\text { weight } \\
\text { (g) }\end{array}$ & $\begin{array}{c}\text { Feed } \\
\text { Assay } \\
\text { (ppm) }\end{array}$ & $\begin{array}{c}\text { Concentrate } \\
\text { assay } \\
\text { (ppm) }\end{array}$ & \% Recovery \\
\hline 10 & 100 & 21.70 & 78.30 & 10.15 & 43.2 & 92.36 \\
20 & 100 & 16.40 & 83.60 & 10.15 & 38.97 & 62.97 \\
30 & 100 & 5.90 & 94.10 & 10.15 & 53.01 & 30.81 \\
40 & 100 & 9.70 & 90.30 & 10.15 & 71.37 & 68.21 \\
50 & 100 & 11.88 & 88.12 & 10.15 & 53.36 & 62.45 \\
60 & 100 & 19.44 & 80.56 & 10.15 & 50.04 & 95.84 \\
\hline
\end{tabular}

Table 4. Assay and \% recovery of Birnin-Gwari gold sand obtained at different feed rates

\begin{tabular}{cccccc}
\hline $\begin{array}{c}\text { Feed Rate } \\
\mathbf{( k g} / \mathbf{h r})\end{array}$ & $\begin{array}{c}\text { Weight of Crude } \\
\mathbf{( g )}\end{array}$ & $\begin{array}{c}\text { Weight of } \\
\text { Concentrate } \mathbf{( g )}\end{array}$ & $\begin{array}{c}\text { Weight of } \\
\text { Tailings (g) }\end{array}$ & $\begin{array}{c}\text { Assay of Concentrate } \\
\text { (ppm) }\end{array}$ & $\begin{array}{c}\text { Assay of } \\
\text { Tailings (ppm) }\end{array}$ \\
\hline 50 & 100 & 56.32 & 43.63 & 12.83 & 9.36 \\
60 & 100 & 52.99 & 47.01 & 26.83 & 10.83 \\
70 & 100 & 32.57 & 67.43 & 93.14 & 6.379 \\
80 & 100 & 16.66 & 83.34 & 25.32 & 2.52 \\
90 & 100 & 47.39 & 52.61 & 27.42 & 8.01 \\
100 & 100 & 41.68 & 58.32 & 47.145 & 7.02 \\
\hline
\end{tabular}




\subsection{Discussion}

Table 1 is showing the chemical composition of BirninGwari gold sand using Energy Dispersive X-ray Fluorescent Spectrometer (ED-XRFS). This reveals that the crude gold sand contains $10.15 \mathrm{ppm} \mathrm{Au}, 0.43 \% \mathrm{Fe}$, $0.05 \% \mathrm{Zn}, 0.43 \% \mathrm{~Pb}$ and other constituent elements in trace form, thus confirms the presence of Gold. Table 2 and Figure 1 presents the result of the fractional sieve analysis of Birnin-Gwari gold sand and the graph showing the percentage cumulative weight retained and passing against the sieve respectively. The two curves in Figure 1 which are a mirror image of each other intercept at $-125+90 \mu \mathrm{m}$ which is in agreement with the result of the chemical analysis of each sieve fraction, $-125+90 \mu \mathrm{m}$ has the highest assay. Hence, this confirms the liberation size to be at $-125+90 \mu \mathrm{m}$.

Table 3 present the yield and assay of gold obtained at varied angles of tilt of the sluice box. It was observed that the highest yield in terms of mass gave $21.7 \mathrm{~g}$ of goldbearing sand at a recovery of $92.36 \%$ assaying $43.20 \mathrm{ppm}$ was at angle $10^{\circ}$, while at $40^{\circ}$ angle of tilt gave a yield of $9.7 \mathrm{~g}$ of gold assaying $71.37 \mathrm{ppm}$ with a low value of recovery of $68.21 \%$. This revealed that more quantity of gold with high impurities was recovered from gold sand at $10^{\circ}$ while keeping all other parameters constant. However, Ata $40^{\circ}$ angle of tilt, we have a higher quality of gold produced than at any other angle of tilt, showing an inverse relationship between gold assay (ppm) and recovery. The reason for this phenomenon could be that the gold in gold sand at $40^{\circ}$ angle of tilt has attained its critical tilt angle to produce the higher quality of gold through the use of water stream to enable its separation and migration into the concentrate. The reverse of this phenomenon could be responsible for low content and higher recovery value of gold in other chosen tilt angles. Hence, inverse relationship was established between gold concentrate assay (ppm) and percentage gold recovery.

Table 4 present the result of the assay in ppm and recovery in the percentage of gold from the processing of Birnin-Gwari gold sand using the sluice box method at different feed rates. From the result, it was observed that gold response to the employed process is more effective at a feed rate of $70 \mathrm{~kg} / \mathrm{hr}$, as it produced gold concentrate assaying $93.14 \mathrm{ppm}$, with its tailing showing $6.39 \mathrm{ppm}$. The reason that (Mitchell et al., 1997) have reported in a different form that the critical feed rate factor of mineral processing very important, that if attained, the particle of gold will respond to the machine used to separate the particle. This condition was only met at $70 \mathrm{~kg} / \mathrm{hr}$ and could not be met by other angles of tilts. Hence, a drawback in their quality as more gangue reported to the concentrate, causing its quantity to increase at the detriment of their quality; hence low assay at lower ppm resulted.

\section{CONCLUSION}

The study on investigating the potentials of sluice box angle of tilt for the beneficiation of Birnin-Gwari gold deposit was reported in two ways: at varying tilt angles and varying rates. This revealed that at varied tilt angle the highest yield of $71.32 \mathrm{ppm}$ was obtained at $68.2 \%$ recovery at an angle of $40^{\circ}$, while at varied feed rate the highest grade was obtained at $70 \mathrm{~kg} / \mathrm{hr}$ as other parameters were kept constant. Finally, the use of a sluice box in processing Birnin-Gwari gold sand revealed that charging at a feed rate of $70 \mathrm{~kg} / \mathrm{hr}$ and tilt angle of $40^{\circ}$ gave high potential to produce a higher grade of gold and this is recommended to be adopted.

\section{ACKNOWLEDGEMENT}

The authors sincerely show their profound gratitude to the Mineral Laboratory of Metallurgical and Materials Engineering Department, Federal University of Technology Akure, for allowing this research bench work to be carried out in their Laboratory and National Metallurgical Development Centre, Jos for the characterization of the ore.

\section{REFERENCES}

Agyei, G., and J. Gordon. (2017): “Effect of Riffle Height and Spacing of a Sluice Board on Placer gold recovery", Ghana Mining Journal, Vol. 17, No. 1, pp. 64 - 72.

Duckenfield, M. (2016): "The Monetary History of Gold: A Documentary History", 1660-1999. Routledge. ISBN 9781315476124.

Garba, I (2002): "Geochemical Characteristics of the Gold Mineralization near TsohonBirnin Gwari, Northwestern Nigeria"Urban\& Fischer Verlag, Chem. Erde 62, pp160-170.

Kankara, I. A. and Darma, M. R. (2016): "A Review of Gold Metallurgeny in Nigeria" Int'l Journal of Research in Chemical, Metallurgical and Civil Engineering. (IJRCMCE). 3(2):294-299.

Metso Mining and Construction (2015): Basics in Mineral Processing Handbook. pp 354.

Ministry of mines and steel development (2010): Gold Deposits Exploration opportunities in Nigeria. pp 1-14.

Mitchell, C.J., Evans, E. J., Styles, M. T., (1997): “A Review of Gold Particle-size and Recovery Methods" British Geological Survey, Mineralogical and Petrology Group, Technical report WC/97/14 pp1-34.

Okwumbu, R. (2020): https://nairametrics.c 2020/08/10/nigeria-to-begingold-production-in-2021-with-the-segilola-gold-project/. Visited page on 24-01-2021.

Veiga, M. M., Metcalf, S. M., Baker, R. F., Klein, B., Davis, G., Bamber, A., Siegel, S., Singo, P., (2006): "Manual for Training Artisanal and Small-Scale Gold Miner" Vienna, Austria: GEF/UNDP/UNIDO, pp 1-152. 